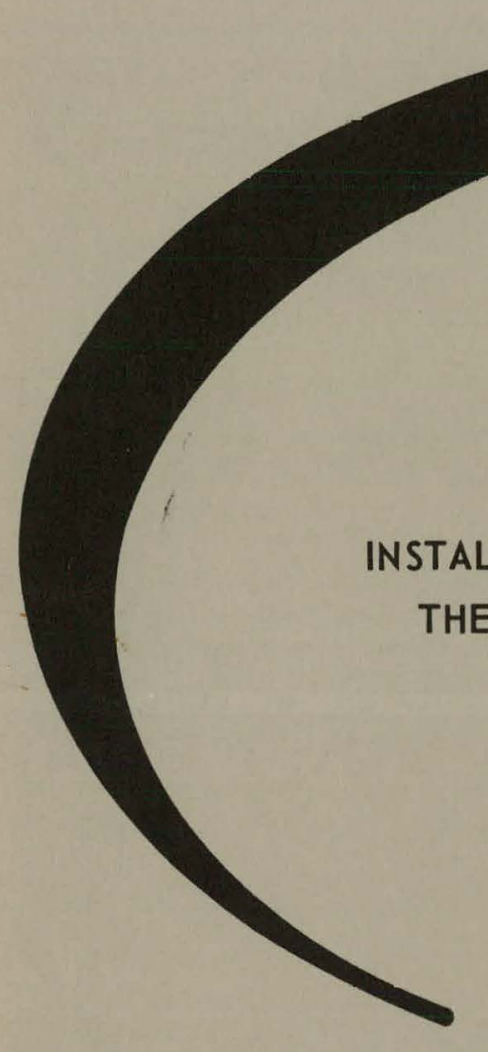

\author{
Andrew J. Johnson \\ Glen A. Shepherd

\section{Dow} \\ (a) \\ THE DOW CHEMICAL COMPANY \\ ROCKY FLATS DIVISION \\ P. O. BOX 888 \\ GOLDEN, COLORADO 80401 \\ U.S. ATOMIC ENERGY COMMISSION \\ CONTRACT AT(29-1)-1106
}




\section{DISCLAIMER}

This report was prepared as an account of work sponsored by an agency of the United States Government. Neither the United States Government nor any agency Thereof, nor any of their employees, makes any warranty, express or implied, or assumes any legal liability or responsibility for the accuracy, completeness, or usefulness of any information, apparatus, product, or process disclosed, or represents that its use would not infringe privately owned rights. Reference herein to any specific commercial product, process, or service by trade name, trademark, manufacturer, or otherwise does not necessarily constitute or imply its endorsement, recommendation, or favoring by the United States Government or any agency thereof. The views and opinions of authors expressed herein do not necessarily state or reflect those of the United States Government or any agency thereof. 


\section{DISCLAIMER}

Portions of this document may be illegible in electronic image products. Images are produced from the best available original document. 


\section{LEGAL NOTICE}

This report was prepared as an account of Government sponsored work. Neither the United States, nor the Atomic Energy Commission, nor any person acting on behalf of the Commission: A. Makes any warranty or representation, expressed or implied, with respect to the accuracy, completeness, or usefulness of the information contained in this report, or that the use of any information, apparatus, method, or process disclosed in this report may not infringe privately owned rights; or

B. Assumes any liabilities with respect to the use of, or for damages resulting from the use of any information, apparatus, method, or process disclosed in this report.

As used in the above, "person acting on behalf of the Commission" includes any employee or contractor of the Commission, or employee of such contractor, to the extent that such employee or contractor of the Commission, or employee of such contractor prepares, disseminates, or provides access to, any information pursuant to his employment or contract with the Commission, or his employment with such contractor.

Printed in the United States of America

Available from

Clearinghouse for Federal Scientific and Technical Information National Bureau of Standards, U. S. Department of Commerce

Springfield, Virginia 22151

Price: Printed Copy $\$ 3.00$; Microfiche $\$ 0.65$ 


\section{INSTALLATION OF A FLAME SPECTROMETER FOR THE ANALYSIS OF RADIOACTIVE SOLUTIONS}

Andrew J. Johnson

Glen A. Shepherd



THE DOW CHEMICAL COMPANY

ROCKY FLATS DIVISION

P. O. BOX 888

GOLDEN, COLORADO 80401

Prepared under Contract AT(29-1)-1106

for the

Albuquerque Operations Office

U. S. Atomic Energy Commission 
RFP-1344 


\section{CONTENTS}

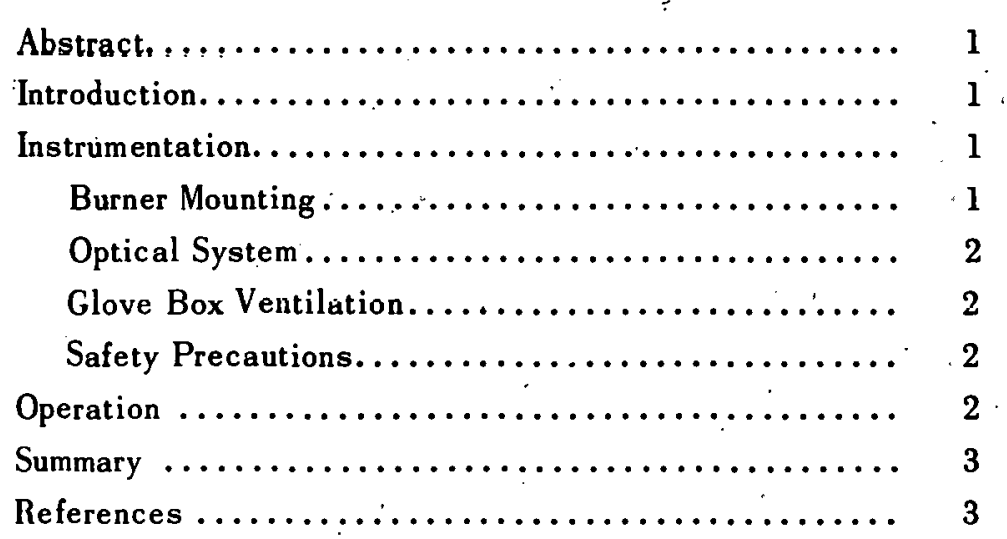


RFP-1344 


\title{
INSTALLATION OF A FLAME SPECTROMETER FOR THE ANALYSIS OF RADIOACTIVE SOLUTIONS
}

\author{
Andrew J. Johnson and Glen A. Shepherd
}

\begin{abstract}
A Jarrell-Ash Model 82-360 Atomic
Absorption Flame Spectrometer has been installed in a specially designed glove box for use in the analysis of radioactive materials. The design and installation of the glove box, the ventilation and safety precautions, and the analytical operation of the instrument are discussed. Examples are given of the types of analyses performed.
\end{abstract}

\section{INTRODUCTION}

Atomic absorption spectrophotometry, within a relatively short time, has proved to be an extremely useful analytical tool and is found in nearly all laboratories performing elemental analyses. One area notable for nonutilization of the instrument is in the analyses of radioactive elements having specific activities greater than uranium-235. These radioactive elements, particularly plutonium-239, present problems not usually found in the handling of conventional materials.

Any.operation involving radioactive materials must be conducted in a safe manner. The radioactive elements are highly toxic; plutonium being termed the most toxic material now handled in large quantities. All work must therefore be performed to keep the element contained. Another problem is contamination of equipment which is in contact with the radioactive material. Maintenance and repairs on the complex equipuent inside a dry box bccomc complioated and tedious. The atomic absorption installation in use at the Rocky Flats Division of The Dow Chemical Company, has been designed to overcome many of these problems.

\section{INSTRUMENTATION}

The Jarrell-Ash Mudel 82-360 Atomic Absorption Flame Spectrometer was selected for the glove box installation because of its modular design. The instrument consists of five components: (1) a turret-type hollowcathode mount, (2) a mechanical chopper, (3) a multipass optical system, (4) a burner, and (5) a 0.5-meter Ebert-scanning spectrometer. All components are mounted on a channel-iron base. No modifications to the instrument were made before installation.
A drawing of the stainless-steel glove box is shown in Figure 1. The box fully contains the burner and its generated off-gases; all other components of the instrument are external to the glove box. The working area in front of the burner is small, but adequate to hold samples ready for aspiration. The weighing, dissolution, and other steps in sample preparation are performed in another glove box adjacent to the burner box. The large section below the wire floor of the box contains four intake filters, each rated at $70 \mathrm{cfm}$, and the waste drain and container for the laminar-flow burner.

\section{Burner Mounting:}

The burner is mounted in the narrow section at the rear of the box. The section is raised about 6 inches off the floor of the box and has a rubber panel on its floor.

Figure 1. Top, Side, and Front Views of Stainless-Steel Glove Box.

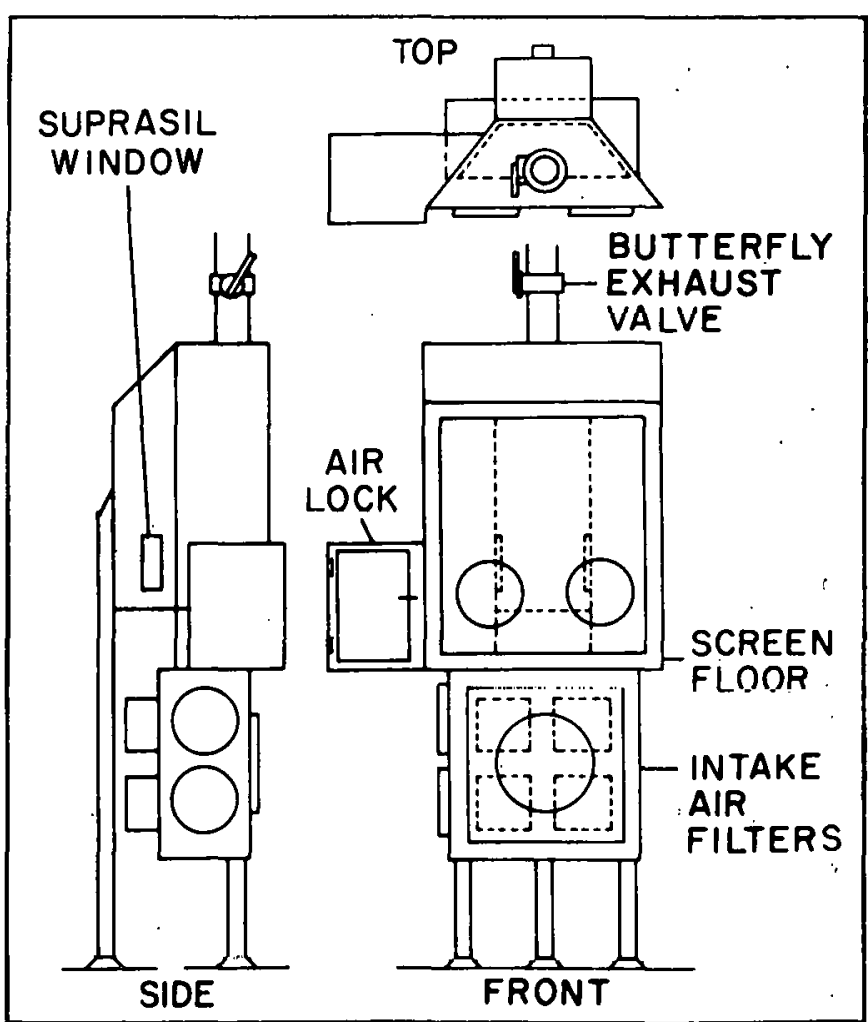


The burner-mount screws pass through the rubber panel and into the original screw holes in the channel-iron instrument base. This rubber section acts as a mechanical insulation between the instrument and the glove box. Any twisting, expansion or contraction, or vibrations in the glove box will therefore have little or no effect on the instrument alignment.

\section{Optical System:}

The original optical system was retained, including the triple pass system. The mirror, lenses, and the periscope are located outside the box where they can be adjusted easily. The optical windows in the box are UV-transmitting suprasil quartz. Unfortunately, these two windows remove $60 \%$ of incident-light energy in the $2500 \AA$ region. The windows also fog and, as a result, can cause an energy loss. The fogging is caused by the close proximity of the windows to the burner, but it is easily corrected by frequent cleaning.

\section{Glove Box Ventilation:}

The air flow through the box is controlled by a butterfly valve in the exhaust line near the top of the glove box. Air is drawn into the box through the filters near the bottom. The air flows up through the large-mesh screening that forms the working floor of the box, it flows past the burner, and then out through the 4-inch exhaust duct. This duct is connected into the glove-box exhaust system of the building.

Concern was first expressed about the operation of an open flame in a glove box connected to the glovebox exhaust system of the building. Specifically, of concern, was the heating effect of the hot off-gases. To measure the highest heating that would be encountered, a nitrous oxide-acetylene flame was operated for 45 minutes in the glove box. Air flow through the box was $280 \mathrm{cfm}$, and was measured outside the intake filters. Temperatures at various locations on the box were then measured with a surface pyrometer. The highest temperature measured was $255^{\circ} \mathrm{F}$, directly over the burner. A thermometer set in the exhaust duct and covering the $200^{\circ}$ to $1000^{\circ} \mathrm{F}$ range did not register a temperature. This indicated that the temperature of the gáses was less than $200^{\circ} \mathrm{F}$.

\section{Safety Precautions:}

The box-enclosed burner presents two possible hazards that are not usually encountered with conventionally installed flame spectrometers. One hazard is the possible collection of combustible-fuel gas around the burner. This could cause an explosion when the burner is first lit. A pressure gauge on the front of the glove box is used to monitor the vacuum in the box. A negative pressure sufficient to prevent gas buildup is always present before the burner is lit.

The other danger is that the burner flame might be extinguished and then combustible gas could enter the exhaust piping and cause an explosion. This hazard is controlled by the use of a small UV flame detector that is connected to a solenoid valve in the fuel-supply line. When the burner is first being lighted, a spring-loaded manual override is used to open the solenoid valve in the fuel line. The flame detector keeps the valve open if the flame is burning. If the flame is extinguished, the fuel supply is automatically shut off.

The flame detector must be located so that it views that portion of the flame which is above the path of light emitted by the hollow-cathode tube. Otherwise, the detector will pick up any UV light emitted by the tube and will hold the fuel valve open even though the flame is extinguished.

\section{OPERATION}

Figure 2 is a photograph of the installation. The electronic controls and fuel-oxidant control panels are located to the right of the glove box. The recorder at the left is mounted on a small laboratory cart so it can be moved. Access to the rear of the instrument, necessary for operation, is through the narrow space used for the recorder storage. Gases used are in a storage rack a short distance away from the glove box. One-quarter-inch stainless-steel tubing is used to supply the gases to the glove box.

The operation of the instrument, in either the flame emission or atomic absorption mode, is the same as that of a conventionally installed instrument. The operator sits directly in front of the burner where all controls are within reach. Once the instrument is set up for a particular analysis, the recorder readout is used for most of the sample analyses, performed in the glove box. The recorder eliminates the need to remove one hand from a glove, secure the glove so that it is not pulled back into the box, write down the meter reading obtained on an aspirated sample, and then again put on the glove.

The negative air pressure maintained in the glove boxes tends to pull the gloves into the box. 


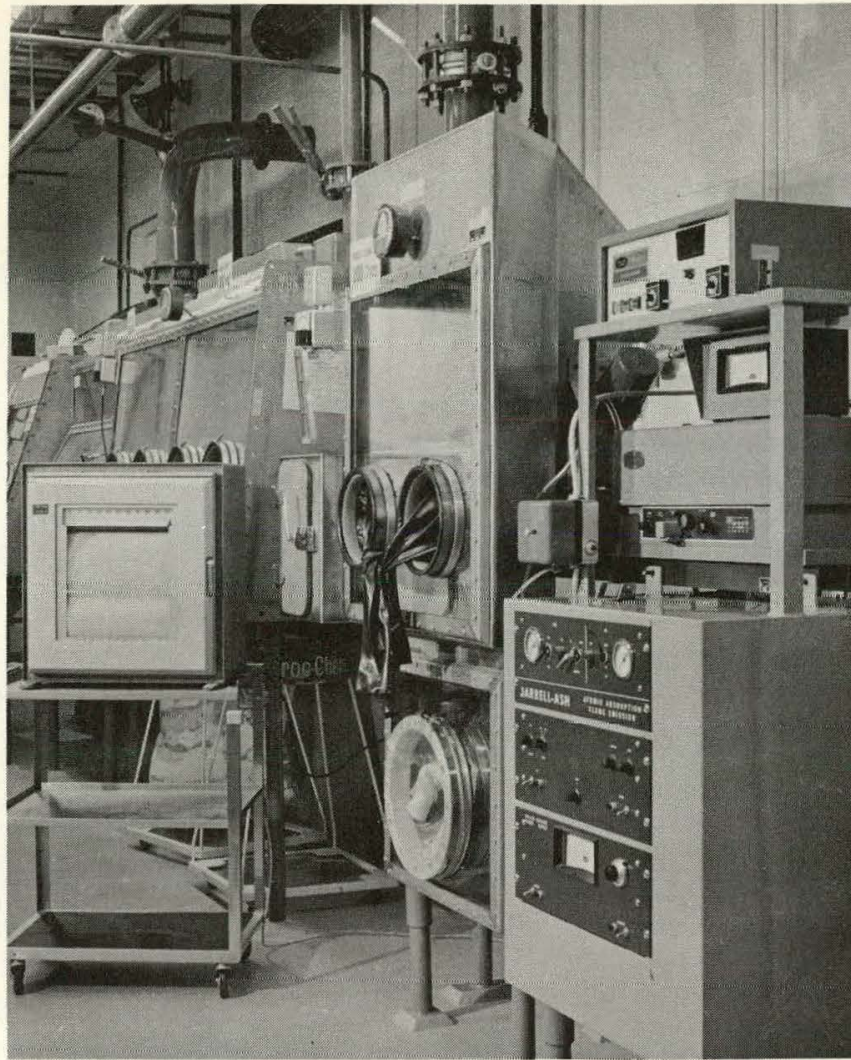

Figure 2. Completed Glove Box Installation.

Therefore a shield is used in front of the burner to keep the gloves out of the flame if they should accidently be pulled into the box.

The instrument has proven to be extremely useful in a number of analyses. The initial analysis was the determination of lithium and sodium in alkali metalplutonium compounds. This is a difficult analysis by other methods, and flame emission techniques were used to perform these determinations quickly and accurately. Table I gives examples of analyses that have been handled by the instrument.

Since the installation of this instrument, reports have been received concerning the installation of two instruments elsewhere. ${ }^{1,2}$ All three differ considerably in the way the instrument was adapted to radioactive work. Our instrument has worked well during the 2 years of operation, and has the advantage of being operated in the same manner and operator position as a conventionally installed instrument.
Table I. Analyses Accomplished by Flame Spectrophotometry.

Determination
Lithium and sodium in alkali
metal-plutonium compounds.
Lead in plutonium solutions.
Tin in neptunium.
Lanthanum in americium solutions.

Method
Flame emission.
Flame emission and
atomic absorption.
Atomic absorption.
Flame emission.

\section{SUMMARY}

A flame spectrometer has been installed in a glove box and is used for the analysis of radioactive materials. The glove box was designed so that all electrical, optical, and gas-handling components are outside the glove box; only the burner is in contact with radioactive solutions. Tests were made of the overall heating effect during operation of the burner. No adverse effects were found on the box, nor were the exhaust gases heated to a dangerous temperature.

The safe operation of the burner is ensured by two measures. Collection of gases around the burner is prevented by the air flow through the burner box. The discharge of flammable gases into the exhaust piping is prevented by an automatic shut off of the fuel supply if the burner flame is extinguished.

Either the flame emission or the atomic absorption mode of operation can be used for sample analysis. Use of recorder readout has proved to be the best method of measuring sample emission or absorption. Types of determinations performed include alkali metals in alkali metal-plutonium compounds, lead in plutonium solutions, and tin in neptunium.

\section{REFERENCES}

1. M. J. Kupper, H. D. Haberman, and M. P. Hughes. Modification of Jarrell-Ash Atomic Absorption Spectrophotometer for Analysis of Trace Elements in Radioactive Solutions. Report ISO-SA-44, Atlantic Richfield Hanford Company, Richland, Washington. 1967.

2. M. Ganivet and A. Benhamou. Atomic Absorption Spectrophotometry Equipment Used for High-Level Alpha Radioactive Samples Analysis. Analytical Chem. Div., ORNL, Presented at the 12th Conference on Analytical Chemistry in Nuclear Technology, Gatlinburg, Tennessee, 1968. 